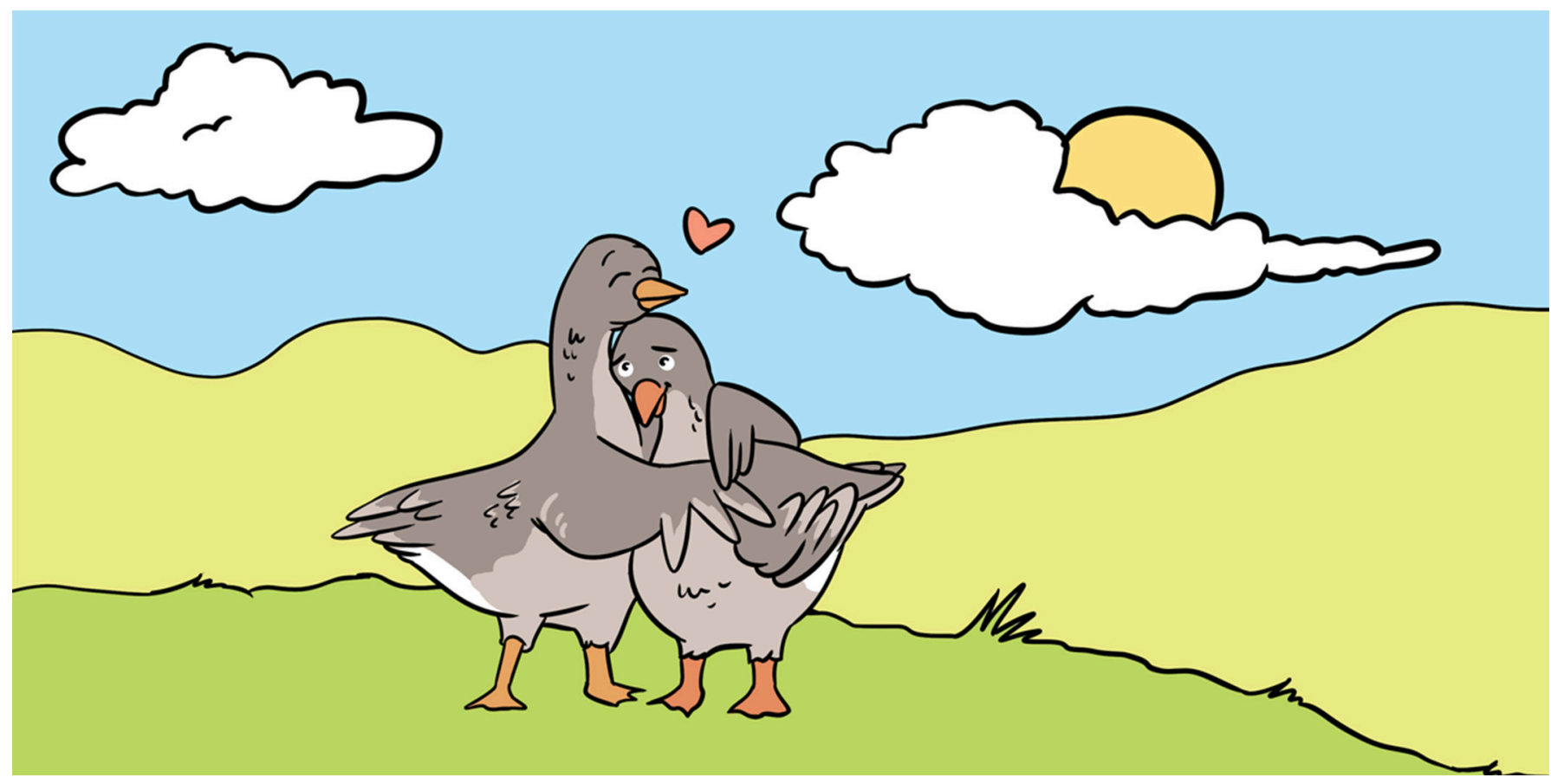

\title{
HOW HAVING A PARTNER AND A FAMILY CHANGES THE STRESS LEVELS OF GRAYLAG GEESE
}

\section{Didone Frigerio $^{1,2^{*}}$, Francesca Hemetsberger ${ }^{1}$ and Claudia A. F. Wascher ${ }^{3}$ \\ ${ }^{1}$ Core Facility Konrad Lorenz Forschungsstelle for Behavior and Cognition, University of Vienna, Gruenau im Almtal, Austria \\ ${ }^{2}$ Department of Behavioral Biology, University of Vienna, Vienna, Austria \\ ${ }^{3}$ School of Life Sciences, Anglia Ruskin University, Cambridge, United Kingdom}

\section{YOUNG REVIEWERS: LAKE ROAD ELEMENTARY SCHOOL AGE: $13-14$}

As a human, having friends might be exciting but it can also be demanding sometimes. Animal societies are not much different: social interactions are known to cause some sort of troubles to the body. This is what we call stress. Among birds, graylag geese are highly social and can be used as a model when investigating why so many animal species live and interact in groups. In this study, we looked at variations in the types of certain cells in the blood of geese, because changes in these blood parameters can be good indicators of stress. We looked at these blood parameters in 105 birds of a free-roaming flock of individually marked graylag geese. We found that blood parameters vary in different seasons and depend on pair-bond status. In conclusion, our results indicate that having a social partner helps individuals to cope with stress in certain seasons. 


\section{GRAYLAG GEESE ARE A GOOD MODEL FOR STUDYING SOCIAL INTERACTIONS IN ANIMALS}

We all know it: having friends might be a lot of fun, but it can also be demanding and even annoying. The non-fun parts of friendship happen mostly when you have to adapt to what your friends are doing, or when you are having an argument. In other words, being social can be stressful, and our bodies react to stress by using additional energy to help us to cope with situations we find difficult.

Animals that live in groups are not much different: social interactions, for example threats or fights, are known to be among the biggest sources of stress. These stressors affect animals physiologically, for example causing their bodies to release substances called stress hormones into the blood stream. This helps them to deal with a challenge [1]. In stressful situations, the body prepares itself for action, for example to run away or to have a fight. To do this, the body uses its energy reserves. In stressful situations, cells that circulate in the blood can also change. Sometimes, high levels of stress can also weaken the immune system and make an animal more susceptible to diseases, including parasite infections [2]. For instance, we know that competitive situations may be especially stressful for low-ranking individuals. However, the presence of a close social partner, like a parent or sibling, may reduce the stress caused by the social environment. This phenomenon is called social support and has beneficial effects on health [3].

Among birds, many goose species are highly social and can be used as model species when doing research about social interactions. Graylag geese, for instance, live in big flocks for most of the year and pair-partners (i.e., male and female) usually stay together for several years, similar to the way humans form couples. Paired birds often stay close to each other during the day no matter what they are doing, for example feeding or resting. Also, after short separations, or simply when they get excited (when other geese are fighting, for example) they greet each other to show that they belong together [4]. Furthermore, graylag geese have strong family bonds and goslings stay close to their parents until the next breeding season.

In general, whether geese have offspring or not plays a major role in their social relationships within the flock. In fact, we know that families tend to win against pairs without goslings in aggressive encounters, and pairs will win in encounters with single, unpaired, birds. As we discussed before, losing fights is stressful for geese and because the likelihood of losing is strongly affected by having a partner or a family, the social situation of geese might also affect whether they more or less likely to be stressed.

In general, geese are faced with varying levels of stress during different seasons of the year, therefore different behaviors can be observed in 
HEMATOCRIT

A measure of the relative volume of red blood cells compared with the total blood volume.

\section{DIFFERENTIAL LEUCOCYTE COUNT}

The relative amounts of different white blood cells in the blood.

\section{H/L RATIO}

A number that indicates the relationship between the amounts of two types of white blood cells, the heterophils, and the lymphocytes. different seasons [5]. For instance, the breeding season, which is in spring, is very demanding and stressful, since the geese need to look for nesting places to lay and incubate their eggs. However, the season fall might not be as stressful, because the goslings are grown up by that time and do not need their parents as much as in spring to defend themselves. Furthermore, in fall the body needs to prepare for the winter, so behaviors are in general more relaxed.

\section{WHAT ARE BLOOD PARAMETERS AND WHICH ONES DID WE STUDY?}

The blood of vertebrates (animals with backbones) is composed of different types of cells, and the relative number of cells per type changes depending on an animal's condition and health. Taken together, the relative numbers of the single cell types determine the composition of the blood cells, which can also change in response to environmental conditions (such as temperature) and social conditions (such as having a partner or not).

The first blood parameter we looked at was hematocrit, which is the percentage of red blood cells in the blood. Red blood cells are responsible for bringing oxygen to the tissues. Hematocrit is known to decrease in response to stressful conditions, but it may also vary with other conditions, such as sex, age, and altitude.

The second parameter was differential leucocyte count, which is a measure of the relative numbers of different white blood cells. There are many types of white blood cells and each type has a different function in terms of defending the body from infections. Lymphocytes are one type of white blood cell, and their number tends to decrease in response to stressful conditions whereas the number of another type of white blood cell called heterophils increases. Therefore, we examined the ratio of heterophils to lymphocytes (H/L ratio), which can be used as indicator for stress.

\section{WHAT DID WE INVESTIGATE?}

We studied graylag geese to see whether social factors, such as being paired or not, and the time of the year, such as the mating season, when the flock splits up into pairs, or the late fall, when the flock is a big social unit, accounted for variations in hematocrit and leucocyte counts. We hypothesized that hematocrit and leucocyte counts would differ between individuals depending on whether they had just a partner or a family. We also predicted that both blood parameters would be affected the most during the breeding season. 


\section{Figure 1}

The hematocrits of graylag geese vary depending on the season. Geese from different social categories (paired with offspring, paired without offspring, and unpaired) show different hematocrit values (shown on the $y$-axis) depending on the season (shown on the $x$-axis). This tells us that especially unpaired geese experience social stress during the mating season, which probably related to the competition for a mate. mating season, in January-February; b. tight winter flock, in November-December;

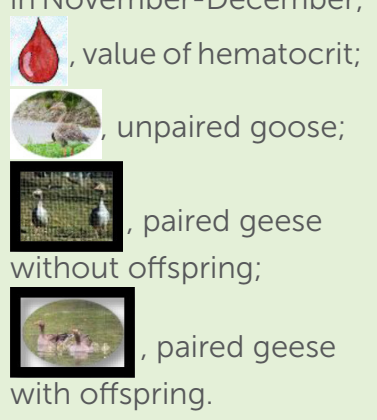

with offspring.

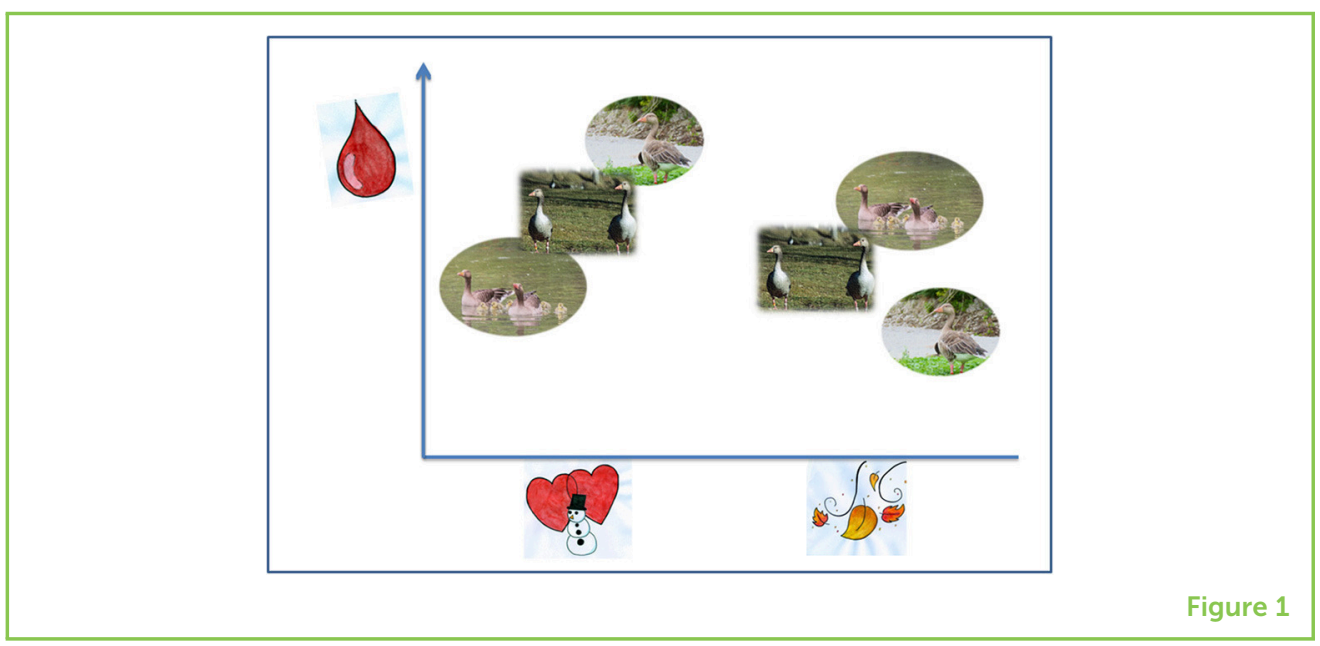

\section{WHERE ARE THE BIRDS WE STUDIED?}

The study was conducted at the Konrad Lorenz Research Station, in the valley of the river Alm in the northern part of the Austrian Alps. A non-migratory flock of graylag geese was introduced there by Konrad Lorenz in 1973. The birds are free to move around and generally spend their time close to the research station, where they are provided with food twice a day, all year round. All geese are marked with colored rings on their legs and are used to the close presence of humans. Data about every individual goose has been collected since 1973, and therefore we know the friends and relatives of each bird in the flock.

\section{HOW DID WE COLLECT THE DATA FROM THE GEESE?}

Data were collected during two periods of the year: (1) during the mating season, in January-February and (2) at the beginning of the winter, during November-December.

We collected a total of 169 blood samples by puncturing a vein on the leg (called the tarsal vein) with a sterile needle. For this purpose, 105 geese were caught by a familiar human observer or in a "trapping enclosure", without chasing the geese or causing them stress. The entire procedure of catching and collecting blood from one bird did not take longer than $10 \mathrm{~min}$. Some geese were caught more than one time; therefore, we had more samples than birds.

We then performed a procedure in which the red blood cells were separated from the fluid part of the blood. In this way, the proportion of red blood cells could be measured just by holding a ruler up to the tube of blood. Another part of the collected blood was smeared onto a microscope slide and prepared so that the different types of white blood cells could be counted under the microscope. 


\section{Figure 2}

$H / L$ ratio is different in geese with offspring vs. geese without offspring. Geese with offspring had higher $H / L$ ratios (shown on the $y$-axis) compared with paired geese that failed to reproduce. This tells us that raising offspring is indeed a stressful experience and that the difference between geese that did and did not raise offspring might reflect what is called the "cost of reproduction".

$\mathrm{H} / \mathrm{L}$ ratio:

paired geese without offspring:

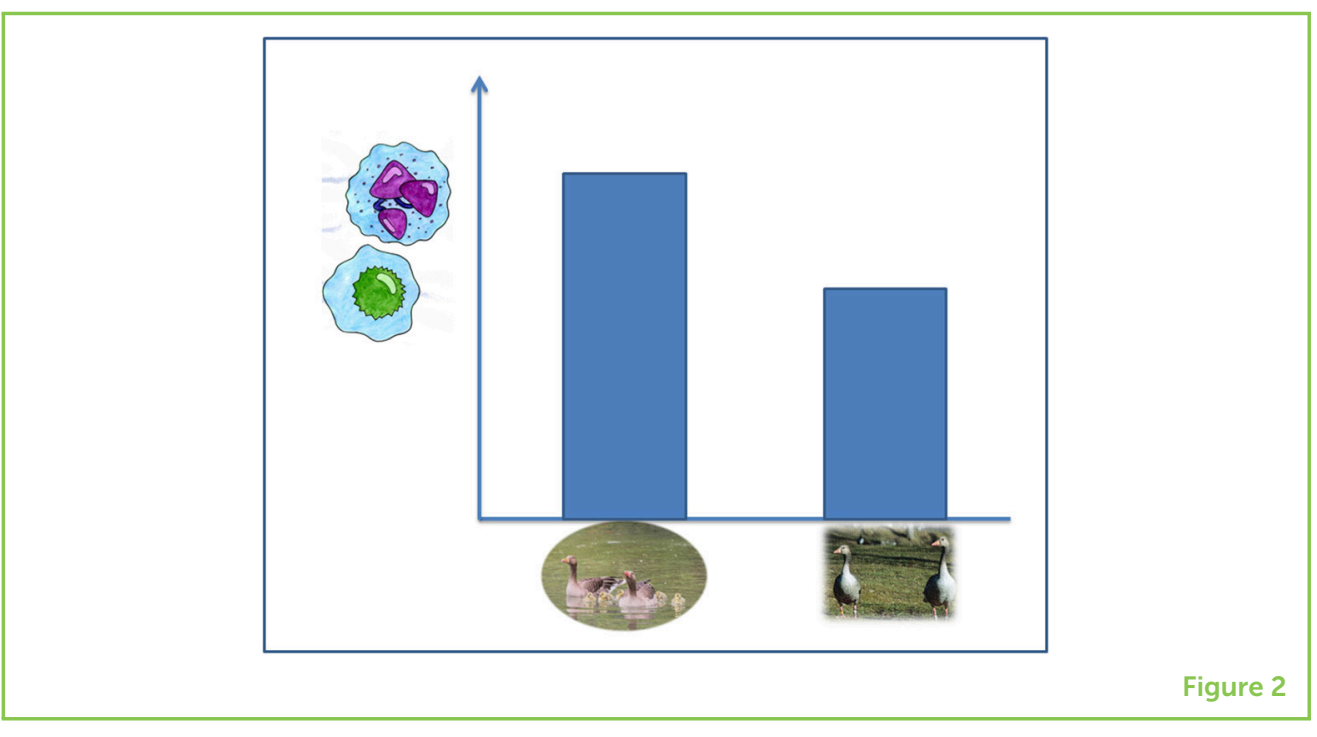

\section{WHAT DID WE FIND OUT AND WHAT DO OUR RESULTS MEAN?}

Our study showed that the social category of graylag geese affects their blood parameters. We found that hematocrit and differential leucocyte counts differed depending on whether individuals were paired, had offspring, or had previously raised offspring successfully.

Interestingly, the relationship between social categories and the blood parameters changed in different seasons (Figure 1). The hematocrit values of unpaired geese were significantly higher during the mating period as compared with the late fall. This suggests that these geese were experiencing social stress, probably related to the competition for a mate. In fact, competing for mates also means engaging in aggressive interactions frequently, which is likely to be stressful for geese.

Both the social category and the season affected the $\mathrm{H} / \mathrm{L}$ ratio. Furthermore, $H / L$ ratios were higher in pairs with offspring as compared with pairs without goslings (Figure 2). The difference between geese that did and did not raise offspring might reflect what is called the "cost of reproduction", because raising offspring is a stressful experience. Humans experience this, too-having a family and children to look after is more stressful than living alone. At least as long the offspring (avian and human) is depending from the parents for caregiving.

In conclusion, our results indicate that the way social factors modulate blood parameters varies between seasons. Having a partner during the mating season reduces stress, but during a relatively low-stress season, partners with offspring experienced increased stress. In other words, in some situations, stable social relationships have advantages for the health of the geese as well as for their reproductive success. 
This means that there are advantages on both a short and a long-term. These results are important because they will help scientists to better understand why group living has evolved so frequently in many animal species.

\section{ACKNOWLEDGMENTS}

Many colleagues were contributing to the success of our study. We gratefully acknowledge Lara Cibulski, Oliver Elsaesser, and Alexander Karl for helping in the field. Josef Hemetsberger, Kurt Kotrschal, and Sonja Ludwig provided scientific assistance. The team of Ilse Schwendenwein at the Clinical Pathology Platform of the University of Veterinary Medicine in Vienna analyzed the blood samples. Larissa Schwaiger contributed proof-reading and Havovi Chichger assisted with language editing. Marianna Hemetsberger drew the figures.

\section{ORIGINAL SOURCE ARTICLE}

Frigerio, D., Ludwig, S. C., Hemetsberger, J., Kotrschal, K., and Wascher, C. A. F. 2017. Social and environmental factors modulate leucocyte profiles in free-living Greylag geese (Anser anser). PeerJ. 5:e2792. doi: $10.7717 /$ peerj.2792

\section{REFERENCES}

1. De Vries, A. C., Glasper, E. R., and Detillion, C. E. 2003. Social modulation of stress responses. Physiol. Behav. 79:399-407. doi: 10.1016/S0031-9384(03)00152-5

2. Vleck, C. M., Vertalino, N., Vleck, D., and Bucher, T. L. 2000. Stress, corticosterone, and heterophil to lymphocyte ratios in free-living Adélie penguins. Condor. 102:392-400. doi: 10.1650/00105422(2000)102[0392:SCAHTL]2.0.CO;2

3. Sachser, N., Duerschlag, M., and Hirzel, D. 1998. Social relationships and the management of stress. Psychoneuroendocrinology. 23:891-904.

4. Lorenz, K. 1988. Hier bin ich-wo bist du? Ethologie der Graugans. München: Piper Verlag.

5. Scheiber, I. B. R., Kotrschal, K., and Weiß, B. M. 2009. Benefits of family reunions: social support in secondary greylag goose families. Horm. Behav. 55:133-8. doi: 10.1016/j.yhbeh.2008.09.006

SUBMITTED: 26 November 2018; ACCEPTED: 30 April 2019; PUBLISHED ONLINE: 15 May 2019.

EDITED BY: Phillip R. Myer, The University of Tennessee, Knoxville, United States

CITATION: Frigerio D, Hemetsberger F and Wascher CAF (2019) How Having a Partner and a Family Changes the Stress Levels of Graylag Geese.

Front. Young Minds 7:68. doi: 10.3389/frym.2019.00068 


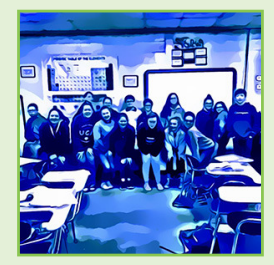

CONFLICT OF INTEREST STATEMENT: The authors declare that the research was conducted in the absence of any commercial or financial relationships that could be construed as a potential conflict of interest.

COPYRIGHT (C) 2019 Frigerio, Hemetsberger and Wascher. This is an open-access article distributed under the terms of the Creative Commons Attribution License (CC BY). The use, distribution or reproduction in other forums is permitted, provided the original author(s) and the copyright owner(s) are credited and that the original publication in this journal is cited, in accordance with accepted academic practice. No use, distribution or reproduction is permitted which does not comply with these terms.

\section{YOUNG REVIEWERS}

\section{LAKE ROAD ELEMENTARY SCHOOL, AGE: 13-14}

This is an eighth grade Science class. We enjoy hands-on activities and labs. We are a mixture of students (athletes, artists, band, and cheer). Most of us are 14 years old. We are ready for spring break and to go to high school!
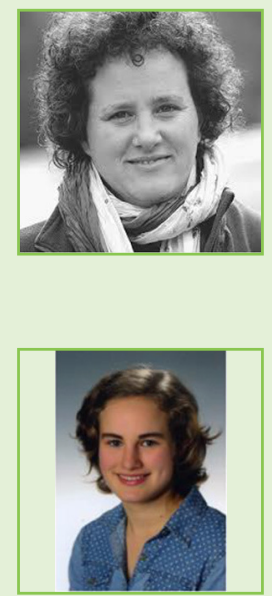

\section{AUTHORS}

\section{DIDONE FRIGERIO}

Didone Frigerio is a behavioral biologist. Her main interest is the relationship between social context and physiology in group-living birds. She loves to work with greylag geese, even though northern bald ibises have also caught her attention recently. She also involves pupils and citizens in her behavioral research, according to the principles of citizen science. ${ }^{*}$ didone.frigerio@univie.ac.at

\section{FRANCESCA HEMETSBERGER}

Francesca Hemetsberger is an undergraduate student. She is very curious and interested in several different topics, especially those related to the research performed by her parents, who are both biologists.

\section{CLAUDIA A. F. WASCHER}

Claudia Wascher is a behavioral biologist interested in costs and benefits of social behavior. She studies the links between physiology, cognition and individual engagement in social interactions, mostly in birds, such as graylag geese and carrion crows. 